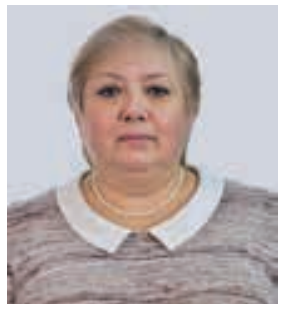

\section{Наталия Борисовна ШРАМКОВА, \\ доцент кафредры} юридического перевода Института юридического перевода

Университета имени О.Е. Кутафина (МГЮА), кандидат фрилософских наук

natashashramkova@ yandex.ru

125993, Россия, г. Москва, ул. Садовая-Кудринская, д. 9

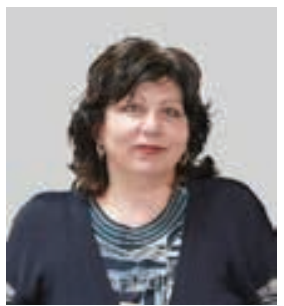

Инна Александровна МАЛЫХИНА, старший преподаватель кафедры иностранных языков № 1 Российского экономического университета имени Г. В. Плеханова in_nin@mail.ru

117997, Россия, г. Москва, пер. Стремянный, д. 36

(C) Н. Б. Шрамкова, И. А. Малыхина, 2020
КРОСС-КУЛЬТУРНЫЕ РАЗЛИЧИЯ В ПЕРЕГОВОРНОМ ПРОЦЕССЕ КАК АСПЕКТ ЭЛЕКТИВНОГО КУРСА «АНГЛИЙСКИЙ ЯЗЫК В ДОГОВОРНОМ ПРАВЕ»

\begin{abstract}
Аннотация. В статье рассматривается важная образовательная и межкультурная составляющая в преподавании юридического английского языка для проведения международных коммерческих переговоров в рамках элективного курса «Английский язык в сфрере договорного права». Статья предлагает практические ситуации и рекомендации по выбору языковых и невербальных средств коммуникации, способствующих успешному проведению переговоров. Их применение позволит сформировать важные языковые и профрессиональные компетенции, необходимые будущим юристам - сотрудникам международных компаний. Ключевые слова: переговорный процесс, «мягкий и жесткий стиль», кросс-культурные различия, переговорный стиль, преимущество в переговорах, взаимная выгода, межличностные отношения, требования, уступки, деловая репутация.
\end{abstract}

DOI: 10.17803/2311-5998.2020.65.1.070-076

I. A. MALYKHINA,

Senior lecturer

of Foreign Languages Department № 1 of Russian Plekhanov University of Economics

in_nin@mail.ru

117997, Russia, Moscow, per. Stremyannyi, 36

\title{
CROSS-CULTURAL DIFFERENCES IN THE NEGOTIATION PROCESS AS A COMPONENT OF THE ELECTIVE COURSE "ENGLISH LANGUAGE FOR THE CONTRACT LAW"
}

\begin{abstract}
The article focuses on the important educational and cross-cultural aspect of teaching English to conduct international business negotiations within the framework of the elective course "English for Contract Law". The article presents real-life cases and instructions on verbal and non-verbal
\end{abstract}




\begin{tabular}{|c|c|}
\hline $\begin{array}{l}\text { УС } \\
\text { УНИВЕРСИТЕТА } \\
\text { имени О.Е. Кутафина (МГЮА) }\end{array}$ & $\begin{array}{l}\text { Шрамкова Н. Б., Малыхина И. А. } \\
\text { Кросс-культурнье различия в переговорном процессе } \\
\text { Как аспект электИвного курса «АНглИйский язьК в договорном праве» }\end{array}$ \\
\hline
\end{tabular}

communication techniques used to achieve success in negotiations. Applying these techniques will enable students to form the language and professional competencies, necessary for the future lawyers, who intend to work for international corporations.

Keywords: negotiation process, soft and hard bargaining style, cross-cultural gap, negotiating style, upper hand in negotiations, win-win tactics, interpersonal relations, excessive demands, price concessions, business reputation.

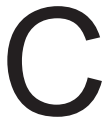

овременный юрист-профессионал должен обладать широким набором навыков и умений, которые органично дополняют знания по специальности, полученные им в вузе, расширяют его возможности в плане карьерного роста и делают его более конкурентоспособным на рынке труда"

Нет необходимости говорить о том, насколько повышаются шансы молодого юриста, специализирующегося в области бизнес- или корпоративного права, найти перспективную и престижную работу, если он владеет иностранным языком. В настоящее время недостаточно только свободно говорить по-английски. Необходимо уметь вести деловую корреспонденцию, составлять тексты договоров и соглашений, переводить устно и письменно, представлять клиента в различных инстанциях на английском языке.

Участие в международных коммерческих переговорах — одна из самых ответственных задач, которые приходится выполнять юристам по коммерческой деятельности. Несмотря на то, что многие представители бизнес-сообщества считают, что юрист вступает в переговоры на заключительном этапе - составления текста договора и вычитки всех условий для целей соответствия данного коммерческого документа действующему законодательству стран-контрпартнеров, в действительности в крупных международных компаниях юристы сопровождают сделку со дня получения оферты и до того момента, когда под договором будут поставлены подписи сторон договора.

Более того, юристам, работающим в области английского договорного права, часто приходится вести предварительную переписку и участвовать в личных встречах с юристами, представляющими интересы их заказчика, поставщика или исполнителя. Именно поэтому знание договорного права как отдельной области англосаксонского права, четкое понимание принятой в этой правовой системе терминологии и конвенциональной структуры английского коммерческого договора представляют первоочередную задачу для юриста. Поэтому подготовительным этапом к переговорному процессу являются длительное и всестороннее изучение текстов различных типов коммерческих договоров на английском языке и подготовка их адекватного параллельного перевода.

Сегодня большинство крупных компаний поручает эту работу штатному переводчику, который работает в непосредственном контакте с юридическим отделом.

1 Калиновская В. В. Содержание элективного курса в рамках профессионально ориентированного обучения // Будущее российского права: концепты и социальные практики : V Московский юридический форум : материалы XIV Международной научно-практической конференции (Кутафинские чтения) : в 4 ч. М., 2018. С. 226-231.

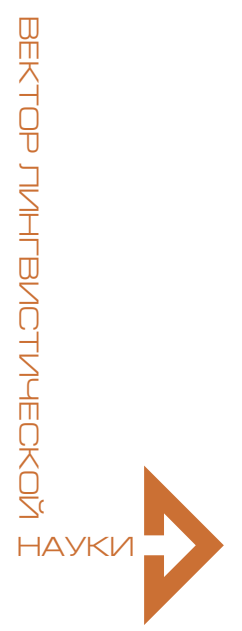


Выпускники Института юридического перевода МГЮА находятся в этом смысле в привилегированном положении, так как они имеют не только прекрасное юридическое образование, но и являются профессиональными переводчиками текстов по юриспруденции.

Однако каким бы длительным и трудоемким ни был процесс составления договора, он может быть начат только после проведения серии встреч, обсуждений, собственно переговоров представителей сторон. А эта работа требует фрормирования навыков делового общения, применения вербальных и невербальных техник, использования или чередования так называемого «мягкого и жестокого стиля», манипуляционных методик (которые совершенно законны с юридической точки зрения), детально продуманной стратегии с распределением ролей и определения общего стиля переговорного процесса своей стороны при четком понимании переговорного стиля и истинных целей контрпартнеров.

Формирование и развитие навыков ведения переговоров на английском языке является одной из задач элективного курса «Английский язык в сфере договорного права» для юристов-переводчиков ${ }^{3}$. В данной статье хотелось бы остановиться на поведенческой стороне проведения переговоров с участием представителей различных культур, имеющих разную цивилизационную идентичность.

Понятие «кросс-культурная осведомленность» всегда упоминается в ситуациях делового общения между представителями разных стран, достаточно сильно отличающихся друг от друга своими традициями, обычаями, отношением к статусу, иерархии, моделями управления и распределения полномочий. Необходимость быть осведомленным о целевой культуре участников переговорного процесса продиктована наличием неизбежных, иногда неосознаваемых, а иногда и трудно принимаемых особенностей восприятия, выражения точки зрения, реакция на слова собеседника, принятия решений ваших деловых партнеров из США, Великобритании, Австралии или иных стран, использующих английский язык для целей делового общения. Этот феномен называется cross-cultural gap - буквально «кросскультурная пропасть», различие между деловыми и общекультурными практиками той или иной страны. Наведение мостов между краями этой пропасти и является задачей преподавателя при ознакомлении студентов с межкультурным взаимодействием и взаимовлиянием различных цивилизаций, которое находит свое отражение при организации и проведении международных коммерческих переговоров ${ }^{4}$.

Достаточно часто в случаях, когда сделка не состоялась, переговорщики автоматически находят этому субъективное объяснение типа «клиент не мог

2 Шрамкова Н. Б. Переводческая компетенция как неотъемлемая составляющая профессиональной компетенции современного юриста // Вестник Университета имени О.Е. Кутафина (МГЮА). 2017. № 11 (39). С. 117-121.

3 Калиновская В. В. Опыт реализации программы «Переводчик в сфрере профессиональной коммуникации (юриспруденция)» в Московском государственном юридическом университете имени О.Е. Кутафина // Актуальные проблемы преподавания иностранных языков в неязыковом вузе в современной образовательной парадигме : материалы научно-практической конференции. М., 2014. С. 35-40.

4 Шрамкова Н. Б. Сущность и специфика межцивилизационных взаимодействий в эпоху глобализации : дис. ... канд. филос. наук. М., 2009. 
заплатить адекватную цену за то качество, которое мы ему предлагаем», «мы не можем предложить им требуемые объемы (товаров или услуг)». Однако очень немногие готовы признать, что сделка не состоялась потому, что они неправильно вели себя в отношении другой стороны переговорного процесса. Именно то, как ведутся переговоры, их определяющий стиль может либо обеспечить успех сделке, либо сорвать ее (то, что англичане называют "make or break the deal"5).

Зачастую непонимание, которое вызывает разногласия, вызвано тем, что лица, участвующие в переговорах, не сомневаются, что их манера поведения, взгляды и представления являются универсально принятыми и должны разделяться всеми. Это большая ошибка. Заставлять представителей из японской компании принимать решение прямо в переговорной комнате является прямым давлением на ваших коллег. Японская корпоративная культура основана на консенсусе и групповой гармонии. Кроме того, срок, необходимый для принятия решения, в Японии может быть значительно бо́льшим, чем сами переговоры. Принципиальные вопросы могут быть решены, но окончательный ответ может поступить через месяц. К этому надо быть готовым при планировании своих действий и подготовке документации.

Или, например, воспринимать динамичную, временами несколько фрамильярную манеру американских переговорщиков как личное оскорбление - означает поставить под угрозу успех всего переговорного процесса. «Ничего личного» девиз европейской и американской деловой культуры. Однако в Китае и практически во всех арабских странах установление хороших межличностных отношений - непременное условие для эффрективного проведения переговоров. Breaking the ice и small talk занимают гораздо больше времени, чем хотелось бы деловым немецким, французским или британским партнерам.

В обобщенном виде мы можем разделить культуры на индивидуалистские и коллективистские. Американцы, британцы, нидерландцы (как они просят себя называть, а не голландцы, и это еще одно проявление кросс-культурной осведомленности, если вам этот факт известен), как правило, полностью полагаются на свои личные усилия и ответственность в вопросах карьерного роста, принятия решений, формирования точки зрения. В переговорном процессе они проявляют независимость личных суждений, открыто совещаются, могут представить аргументированные возражения или выступить с контрпредложением. При ведении переговоров с представителями этих культур необходимо:

1) вести себя уверенно;

2) быть готовым отстаивать свои интересы и требования жестко и аргументированно;

3) быть готовым выдвинуть свои возражения или указать противной стороне на слабость и несостоятельность их требований или условий. Преимущество на таких переговорах будет у той стороны, которая проявила бо́льшую инициативу, напористость, показала твердость своей позиции и хорошо «прочла» все слабые места в позиции контрпартнеров.

5 Нестерова Л. В., Малыхина И. А. Обучение иностранным языкам в контексте межкультурной коммуникации // Инновации в образовании. 2017. № 8. С. 73-81.

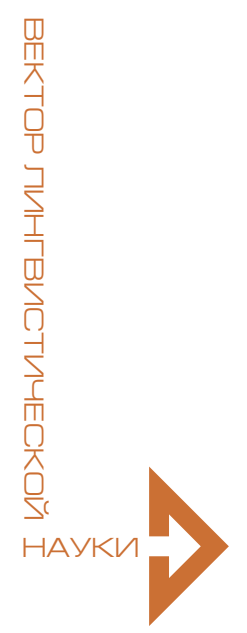


В то же время, большинство представителей азиатской, арабской или африканской культурной группы явно демонстрируют коллективизм в переговорном процессе. Они подчиняют свои личные цели интересам группы, к которой принадлежат, и стараются избегать любых разногласий или конфликтов с другими членами группы. При проведении переговоров с представителями этого типа корпоративной культуры следует:

1) позиционировать себя как сотрудника вашей компании или представителя переговорной группы;

2) начать беседу с разговора о компании ваших контрпартнеров, выразить уважение к деловому успеху или последним операциям этой компании, за которыми вы внимательно следили;

3) вести беседу в спокойной и неторопливой манере, предоставив другой стороне задавать темп разговора;

4) строить переговоры так, чтобы члены вашей команды принимали участие в беседе и проявляли единодушие «как члены одной дружной семьи»;

5) помнить, что групповые встречи с коллективистскими культурами часто имеют своей целью либо обмен информацией, либо окончательное подтверждение достигнутых договоренностей. Если ваша цель - добиться уступки или более детально обсудить проблему с вашим корейским или китайским контрпартнером, лучше всего организовать личную встречу в неформальной обстановке. Приглашение на обед в ресторане национальной кухни может оказаться эффективным способом решения проблемы в режиме face-to face.

Традиционно было принято также выделять так называемые низкоконтекстные и высококонтекстые культуры. Первый тип - те, в которых люди стремятся выразить свою позицию в ясных, четких и однозначных терминах. Иными словами, люди говорят именно то, что имеют в виду. Представители США, Скандинавских стран и Германии ведут себя именно так. На переговорах с ними:

1) следует воспринимать то, что вам говорят, буквально. Если вы слышите, что выполнить то, о чем просит ваша сторона, будет трудно, это значит «выполнить возможно, но будут сложности»;

2) не следует воспринимать открытые возражения как личный выпад против вас или демонстрацию неприязненного отношения. Это проявление открытости и честности переговорной позиции.

Напротив, представители культур высокого контекста (КНР, Япония, арабский мир и (!) Франция, как правило используют широкую имплицитность в бизнесобщении. От вас ожидается понимание подтекста, заложенного в то или иное высказывание, основанное именно на знании культурной специфики страны или региона, который представляет для вас целевую культуру. В этом смысле британцы с их недосказанностью, самоиронией и привычкой употреблять прием аллюзии в речи, демонстрируют именно такой тип культуры. На основании этого при проведении переговоров не следует воспринимать буквально некоторые слова или предложения, произнесенные вашими контрпартнерами.

Так, если представитель японской переговорной команды говорит: “I am afraid, it will be difficult”, читайте это как «Это невозможно, мы этого не будем делать». Надо понимать, что японская культура общения не позволяет употреблять слово «нет» в качестве отказа, ибо это нарушает гармонию общения и наносит личное 
оскорбление другой стороне. Правильная интерпретация этого высказывания возможна только при знании межкультурных различий представителей разных цивилизаций. Ваша тактика - ждать, слушать и вежливо переспрашивать.

И в заключение хотелось бы предложить несколько общих поведенческих рекомендаций в процессе переговоров, независимо от стадии переговорного процесса.

1. Используйте нормативный официально-деловой английский язык. Не старайтесь украсить вашу речь идиомами, различными фразовыми глаголами из повседневной жизни или большим количеством латинизмов. Ваша цель - быть понятым, а не произвести впечатление своими лингвистическими познаниями. Вы есть то, как вы говорите. Деловая репутация вашей компании должна проявляться и в корректной грамотной речи ее сотрудников.

2. Будьте наблюдательны. Старайтесь слушать другую сторону, а не только слышать и прокручивать в голове ваши условия.

3. Не бойтесь прервать собеседника, если вы не поняли, что он имел в виду. Потом может быть поздно трактовать зафиксированное в письменной фрорме условие. Результатом может стать спор, который придется разрешать посредством арбитража.

4. Все проверяйте и выверяйте до последней буквы, до точки или запятой. Классический школьный пример «Казнить нельзя помиловать» имеет свои аналоги в юридической практике. Это особенно касается таких условий, как before, by, not later than, смысла модальных глаголов в договоре may, will, shall, is to и др. На практике вычитка договора может сопровождаться такими вопросами:

- Sorry, I am not familiar with that expression. What do you mean by "high level proposal?"

- Sorry, can I check that?

- When you say "eventually", what do you mean? Does it mean "finally" or "possibly"?

- Are you saying that you can't meet the deadline?

5. Перепроверьте числа, даты, номера, сроки, указанное время, буквы в именах, фрамилиях и указанных адресах пунктов отправки и доставки.

6. Не используйте длинные, перегруженные предложения. Каждое предложение должно содержать понимаемую мысль.

7. Продумайте фрормулировки, которые вы собираетесь использовать, проговорите свои мысли и убедитесь, что они содержат message, т.е. фрорма вашего высказывания четко передает содержание.

8. Контролируйте использование невербальных средств, так как они могут выдать ваши истинные намерения или вызвать раздражение контрпартнеров. Вместе с тем научитесь понимать характерные жесты и мимику представителей целевой культуры. Это поможет найти правильный подход к ведению коммуникации, а возможно, и понять недосказанные или намеренно скрываемые мысли ваших деловых партнеров.

Изучение кросскультурных различий и их роли в переговорном процессе представляет, безусловно, обширный и увлекательный аспект элективного курса «Английский язык в сфрере договорного права» и способствует повышению мотивации студентов - юристов, получающих специальность «Переводчик в сфрере профессиональной коммуникации». 


\section{БИБЛИОГРАФИЯ}

1. Калиновская В. В. Опыт реализации программы «Переводчик в сфере профессиональной коммуникации (юриспруденция)» в Московском государственном юридическом университете имени О.Е. Кутафина (МГЮА) // Актуальные проблемы преподавания иностранных языков в неязыковом вузе в современной образовательной парадигме : материалы научно-практической конференции. - М., 2014. - С. 35-40.

2. Калиновская В. В. Содержание элективного курса в рамках профессионально ориентированного обучения // Будущее российского права: концепты и социальные практики : V Московский юридический форум : материалы XIV Международной научно-практической конференции (Кутафинские чтения) : в 4 ч. - М., 2018. - С. 226-231.

3. Нестерова Л. В., Малыхина И. А. Обучение иностранным языкам в контексте межкультурной коммуникации // Инновации в образовании. - 2017. № 8. - С. 73-81.

4. Шрамкова Н. Б. Переводческая компетенция как неотъемлемая составляющая профессиональной компетенции современного юриста // Вестник Университета имени О.Е. Кутафина (МГЮА). — 2017. — № 11 (39). — С. 117-121.

5. Шрамкова Н. Б. Сущность и специфика межцивилизационных взаимодействий в эпоху глобализации : дис. ... канд. фрилос. наук / Российский экономический университет имени Г. В. Плеханова. — М., 2009. 